\title{
人工内耳幼览症例への援助
}

\begin{abstract}
大森千代美
要 約: 人工内耳幼児症例へは, 言語面だけでなく発達全般を視野に入れた援助を考慮しな くてはならない. 今回は 5 歳代に人工内耳を装用した 1 例について, 術前から人工内耳装用後 1 年までの遊びや対人関係の発達, 聴覚を用いた話しことばや構音の獲得の 4 点について観察 し, 幼児症例への援助の在り方を考察した。症例は 1 歳 9 力月で補聴器を, 5 歳 11 力月で人工 内耳を装用。術前から母親とことばでやりとりしながらごっこ遊びを展開しており, 人工内耳 装用後は, 話題や状況から推測したり, 読話をすることで能動的にことばの聞き取りを補って いた。装用後 1 年間で多くの子音を自然習得した症例は, 友達とことばでやりとりするように なった。その過程をみると大人とのことばのやりとりが育つ過程と共通していた．すなわち人 工内耳幼児症例への援助としては, 術前から遊びを通して動作的理解やことばのやりとりを育 てることが重要だと思われた。
\end{abstract}

索引用語 : 人工内耳幼児症例, 発達, 術前指導, やりとり

\section{Help for Infants with Cochlear Implant}

\section{Chiyomi Ohmori}

\begin{abstract}
Help for an infant with a cochlear implant must give careful consideration to aspects of total development as well as speech and hearing ability. In this study, the developmental process of an infant implanted at five years old was observed from four points of view : i.e. playing activities, relationships with play peers, hearing capacity and articulation. Observation was carried out from the preoperative period through the first year after implantation. We also discussed the kind of help needed by this patient.

The subject began to wear hearing aids from the age of one year nine months ; implantation was performed at five years eleven months. Long before the operation he started to enjoy symbolic play with his mother/teacher through verbal and gestural interactions assisted by lip-reading. After implantation, he actively added auditory capacity to his communication with the help of topics, situations and lip-reading. One year after the operation he acquired a variety of consonants and started to interact verbally with his friends. This process was similar to the process he followed with his parents/teacher.

In conclusion, an infant with a cochlear implant needs help in the form of preoperative play interactions enriched by his parents/teacher, which enable him to develop cognitive and verbal capacities.
\end{abstract}

香川こだま学園：テ 760-0080 高松市木太町 1997-3

Kagawa Kodama Gakuen Day Care Center for Children with Impaired Hearing : 1997-3, Kita-cho, Takamatsu, Kagawa 760 $-0080$

原稿受理：2001 年 4 月 23 日 
Key words : infants with cochlear implant, development, preoperative education, interaction

\section{はじめに}

人工内耳幼児症例は心身の発達途上にある子どもを 対象としている点で成人例と異なる取り扱いを必要と している.その援助については言語面だけでなく，認 知や社会性, 運動能力も含めた幅広い視点を必要とし ている.さらにその視点に立てば, 療育担当者は子ど もが「援助を必要としている点」とその援助をもとに 「自分で獲得するであろう点」を別しておく必要があ る.そこで幼児期後半に人工内耳を装用した 1 例の心 身の発達と音声言語獲得過程を, 過去を振り返る形で, 術前と術後にそれぞれ子どもが母親や指導者, 友人と の社会的な関わりの中で能動的に獲得したことを考察 し，人工内耳幼児症例への援助の在り方を考える.

\section{方法}

\section{1. 対象}

2001 年 3 月 31 日現在 9 歳 1 力月の男児. 乳児期の 身体発育は正常であった。 1 歳 9 カ月, 補聴器を装用 し, 以後当園に週 2 回通園. 5 歳 10 力月, 左耳に人工 内耳埋込み術を行った。術前の平均聴力は, 右 $104 \mathrm{~dB}$, 左 $113 \mathrm{~dB}$ (図 1 )。 5 歳 7 力月 WPPSI 知能検査では 言語性 IQ 86, 動作性 IQ 115, IQ 100 で重度難聴にもか かわらず言語発達は概ね良好だった。現在は小学校 5 年生だが, 友達とのことばのやりとりには全く問題が ないと母親はいっている。 また知らない人にも自分か

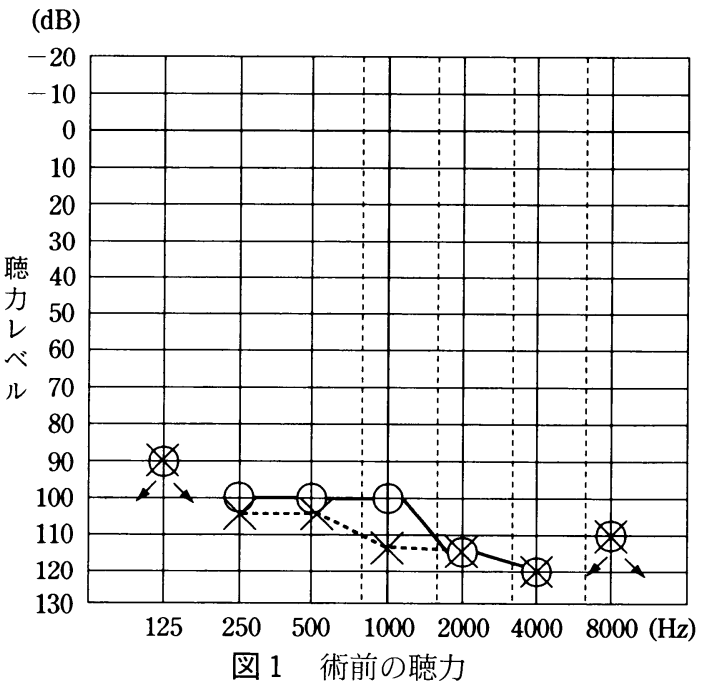

ら話し掛けてやりとりしょうとする積極性がみられ る.

\section{2. 方法}

対象児 1 歳 11 力月から 6 歳 11 力月（人工内耳装用 1 年) までの指導記録簿と療育場面を録画したビデオ ビデオテープ 88 本をみることで1)手術に至るまでの 心身と遊びの発達, 手術後の(2)聴覚を用いた話しこと ばの獲得, (3)構音獲得, (4)友達との関わりの 4 点につ いて観察筆記記録し，指導により育った点と自然に育 った点とを明らかにし人工内耳小児例に必要な援助を 考える.

なお，構音の獲得については以下のような方法で検 討した. 術前 1 本, 装用後の 1 年間に 9 本, 計 10 本の 自由遊び場面を録画したビデオテープからそれぞれ発 話された順に 100 語を取り出し, 筆者と共同研究者で 繰り返し聴取し国際音声記号で表記した。そのうち子 音について,ことばの中で構音されるべき音が実際に どのような音として構音されたり省略されたかと, 構 音された子音が $50 \%$ 以上の割合で構音されるように なった時期を安定した時期として調べた。

\section{結果および考察}

\section{1. 心身と遊びの発達}

はじめに本児が人工内耳を装用するまでにどのよう な遊びをし，その中でどのようにやりとりを展開した かをみた。

1 歳 11 力月，全身を使って指導者と滑り台を楽し む. 前方に座った指導者が滑ろうとすると笑いながら 背中を押す。指導者が押されて滑ると喜び,「もう 1 回」 という身振りをしてから自分も滑り下りた。二人で身 体を使って同じ行動をすることで，相手との気持ちの 共有を楽しんだ。このように行動を模倣し合い, とも に楽しむ関係がやりとり発達の原点であり,ことばの 獲得の土台となる。

2 歳 6 力月, 園庭で本児は指導者がとんぼを捕まえ ようとして逃げられたのをみた後，「オーエー(こうへ い)」（がする）と自分を指差し，とんぼを網で捕まえ 指導者に渡すフリをしてごっこ遊びを始めた。母親も とんぼを欲しがると，指導者にしたのと同じようにと んぼを捕まえて渡すフリをする。母親が受け取ったと んぼが逃げたフリをし,「もう 1 回頂戴」と身振りとこ とばで伝えると，本児は指導者の手からとんぼを取っ て母親に渡すフリをした。 
母親や指導者ととんぼ取りをした共通の体験を基に 自分のイメージを表現するだけでなく，母親のイメー ジも受け入れ動作的にやりとりしている。このように 子どもは, 親密に関わり合う人との間で共通の体験を 土台としてイメージを共有し，それに対する相手の意 図とそれを表す身振りや口の動きを取り込み, これに 音声情報を合わせてことばとして身につけていくと思 われる。

5 歳 3 力月, 母親に熊のぬいぐるみを持たせ子ども の役を与え, 自分は父親役をとる. 買物に行きあれこ れ玩具を選ぶフリをした後ハンドカーを持って母親の 待つ家に見立てた場所に戻り,「ウバッ,オオーアンバ ッウバアンイッ オイアエオ アッエイエアエア ッ.(熊お父さんは 熊さんにおみやげを 買って きてあげた)」といって渡す。構音は不明瞭だが，ほぼ 正常に発達した概念とそれを意味することば（語彙） を遣ってごっこ遊びをしている，本児と母親それぞれ が家庭生活という共通のイメージの中で，あれこれ想 像して動き，ことばで役割を演じるようになった。

2 歳 6 力月の頃に述べたように, 本児はこの時期ま でに母親や指導者とともに身体を使って遊び，共通の 体験とイメージの共有, その中でのことばや身振りを 使ったやりとりから発音は不明瞭ながらことばを遣 い, そのさらなる発達が予想されるまでになった。ご っこ遊びはことばの発達に重要な役割を持ったと考え る.

5 歳 5 力月, 友達への関心は強く一緒に遊ぼうとす るがやりとりは成立しない。関わりを持ちたくて身体 ごとぶつかっていく.

本児の友達のみえちゃんがプレイルームの中で人形 を手にして，赤ちゃんを連れて公園へ散歩に行くつも りで遊んでいた。 そのことを知った本児は，「オーエン イバッ ワウイ オッアンア オウッ(こうえんには わるいおっちゃんがおる)」「オオーイイウウ（ころし にくる)」と自分のイメージを表現する．しかしみえち やんには伝わらず，彼女は赤ちゃんの世話を続ける， 本児は悪者をやっつけると違ったイメージを抱きなが ら遊ぶ。

身近な大人とはイメージを共有しことばのやりとり ができるが，友達の気持ちはまだ理解しない.イメー ジを共有できず, 構音も未分化なため一緒に遊べなか つた。

\section{2. 聴覚を用いた話しことばの獲得}

次に人工内耳を使い始めて子どもに生じた変化をみ る.まず聴覚を用いて話しことばを聞き取っていく様 子を観察した。
5 歳 11 カ月 (装用 2 週間), 扉の向こうの男性指導 者が「おばけはいないよ」というと，聞こえたとおり に発語を模倣するが，母親や指導者にはことばとして 聞き取れず意味不明であった，本児もことばとして理 解していない。そこで指導者が「おばけはどうした の?」と口元をみせて話題を理解する手がかりを与え た後, 再び男性指導者が「おばけはいないよ」という と「おらんの(いないの)」と理解した。この時期はま だ聴覚だけではことばを聞き取れないことが多く, 話 題や状況から類推して理解しょうとしていた.

6 歳 4 カ月 (装用 5 カ月), 指導者がセラピーボール に隠れて差し出すお拉けの抢面を, 玩具の鉄砲で撃つ. 指導者が「はずれ」というと，「ナーネ」と聞こえたと おりに模倣するが意味は理解していない.もう一度指 導者が「はずれ」というと，「ナニイイヨン？(なにを いってるの? )」と母親に問い返し，「はずれ」と母親 がいうその口元をみて理解した。再び指導者が「はず れ」というと今度は正しく聞き取り，その後「はずれ」 は 1 回で聞き取れるようになった。

野中ら ${ }^{1)}$ が述べているように, 術前の言語獲得の補 助手段であった読話が, 新たに入力されるようになっ た音声言語に意味を結びつける役割を果たし，ことば の聞き取りを補うことが確認された。

さらに「はずれ」を聞き取った後, 同じ遊びの中で 「あたり」ということばを 1 回で聞き取った。遊びの中 で「対」の概念として理解していたことばの一方,「は ずれ」を聴覚的に聞き取ると，他方「あたり」をそれ と関係づけて容易に獲得すると思われた。

人工内耳からの聴覚情報ではまだ「ことば」（話しこ とば）と「意味」の結びつきが不十分であった本児は, 聞こえてきた音を自分と指導者との関わりの中で, 今 まで遊びの中で培ってきた動作的経験と概念とを照合 して類推し，ことばとして聞き取ったと思われる。こ の場合子どもが人や物と関わった経験を豊かにもって いるほど，聞こえてきた音は子どもにとって意味ある ものとして取り込まれやすい.

中村 ${ }^{2}$ は不十分な聴知覚への対応として(1)聴覚学習 とそれによる聴知覚の進展, (2)補助手段の利用がある としているが, 本児は遊びの中で能動的にこれらのこ とを行ったと思われる。

6 歳 11 力月 (装用 1 年) では, 本児は母親や指導者 相手に, 話題がわかっていれば相手の口元をみないで 簡単な会話が成り立つようになった。

\section{3. 構音の獲得}

術前, 装用後の自由遊び場面での本児の発話を, 先 に述べたようにビデオテープを繰り返し聴取し, 国際 
音声記号で書き取った資料から人工内耳装用 1 年間の 構音の自然習得過程を観察した.

術前から，母音は 5 種類に区別して構音できていた が，子音は両唇音 $[\mathrm{m}][\mathrm{b}][\mathrm{p}]$ はすべて $[\mathrm{b}] て ゙ ，$ その他の子音は声門破裂音で構音していた。

人工内耳装用後, 声門破裂音は自然に減少し始めた (図 2, 図 3). 替わって次に述べるような子音がみられ 始めた。6 歳（装用 1 力月）には［ooaomoi（どれが おもい?)], [ f ame(ダメ)], [anne ?o:e:mno ? i ? i ? a ? a o ?o? (あのね こうへいくんの みっ きーさんは拄とこ)]などの発話が観察された。両唇 鼻音 $[\mathrm{m}]$ が構音されるようになり, 歯茎鼻音 $[\mathrm{n}]$ は時に正しく, 時に硬口蓋鼻音 $[\mathrm{n}]$ に置換して構音さ れた。また,有声の歯茎破裂音 $[\mathrm{d}]$ は硬口蓋破裂音 $[\mathrm{f}]$ に置換して構音されていた。

6 歳 1 力月(装用 2 力月), 友だちとじゃんけんをし, [jance?o？ ? acca（じゃんけんぽん かった］と いう. 無声の歯茎破裂音 [ $\mathrm{t}$ ］功硬口蓋破裂音 [ c ] で構音されるようになった。

6 歳 2 力月 (装用 3 力月), ごっこ遊びの中で [ ceppo fe u cce(てっぽうで うって)]というなど無声両 唇破裂音 $[\mathrm{p}]$ が構音されるようになった.

さらに 6 歳 8 力月 (装用 9 力月) には [ajau Sicce (は やくして)]といい, 硬口蓋歯茎摩擦音 [j] が観察され た.

次にこれらの子音が $50 \%$ 以上の割合で構音される ようになった時期をみた。図 4 に示すように $[\mathrm{m}][\mathrm{m}]$ [ f ] が 1 力月後, [c] が 2 力月後, [ p ] が 3 力月後,
声門(破裂)音 $\square$ 声門音 目硬口蓋音 四唇音 その他＼cjkstart血軟口蓋音口歯茎音

(\%)

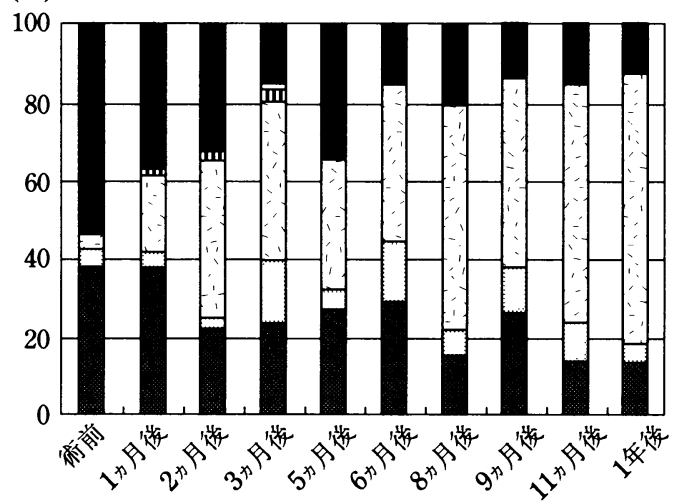

図 2 子音の割合（構音点別）
[S] が 9 カ月後に 50 \%以上の割合で構音されるように なった。

構音獲得の順序は, 構音点からみると両唇音, 硬口 蓋音, 硬口蓋歯茎音の順で健常児の構音発達とほぼ同 様の順序であった (大森 2001) ${ }^{3)}$ 。構音様式からみると 鼻音, 有声破裂音, 無声破裂音, 無声摩擦音の順であ った。健常児では幼児期前半からみられる軟口蓋音や 破擦音がまだみられていないが，これが人工内耳症例 の構音獲得の特徵か否か (これらの音は構音指導を必 要とするか否か）は今後の観察を待たなければならな い.今回の観察期間内には特に系統だった構音訓練は 行っていないが，人工内耳装用後遊びを中心とした生 活の中でのやりとりを充実させる術前からの療育方針 のもとで, 1 年間に多くの子音が獲得された.

筆者は先に本症例を含めた 4,5 歳代での人工内耳 装用児 2 例の 1 年間の構音の自然獲得について観察 し, 構音点でいえば舌尖音と軟口蓋音以外の, 構音様 式でいえば破擦音以外の構音を自然獲得できたと報告 した ${ }^{3)}$.すなわち幼児期後半に人工内耳を装用した場 合，まず第一に日常のやりとりの充実を図り，少なく とも 1 年間は構音発達を観察し, その後で構音指導の 要否を検討すべきと考える，2，3 歳での早期装用例 では自然獲得の可能性がさらに大きく, 経過観察が重 視されることはいうまでもない.

\section{4. 社会性の発達}

前に述べたようなことばの聞き取りや構音の改善が 友達との関わりにもたらした変化をみた。

人工内耳装用直後から, 友達の声に気付くようにな
(声門)破裂音 目 有声摩擦音 口鼻音 その他

而 無声摩擦音 有声破裂音

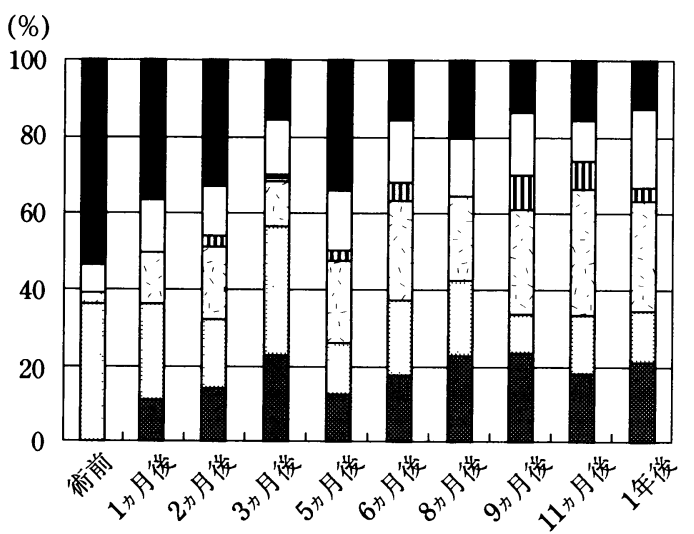

図 3 子音の割合（構音様式別） 


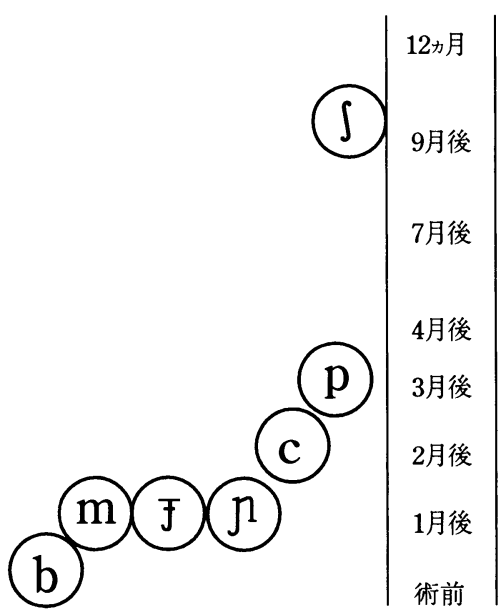

図 450 \%以上構音するようになっ た時期

つた本児は, 装用 2 週目には友達に接近することが増 え，何気なく目を合わせたり，行動や音声を真似たり するようになった。それとともに友達に同調し仲間意 識を持って行動するなど気持ちも共有しょうとするよ うになった。その結果動作的やりとりが増えた。

6 歳 0 力月 (装用 2 力月), 読話を併用すると状況の 理解とあわせて友達のことばが理解でき始めた。

ある日，友達がジャンケンで後出しをする．友達が 「ヤッター, しんちゃんの勝ち」というと, 本児は「イ アウ，オーエーア アッタンデ（違う，こうへいが勝 ったんで)」と自分の勝ちを主張した。また，ある日本 児はビデオの撮影を嫌がり, カメラマンを部屋から締 め出した，友達が「どうして戸を閉めるの?」と聞く と, 本児は「アンネ ヨーオエッエー八 オバエ（あ んね，ようこせんせい=カメラ担当はおばけ)」と答え た。人工内耳により聞き取りが向上したため, 友達と の会話も成立するようになったと思われる。

6 歳 2 力月（装用 3 力月）就学後, 登下校時は友達 と待ち合わせをして一緒に行き帰りする，学校から帰 ると毎日友達の家に遊びに行くなど友達との関わりは さらに増えた。それとともにクラスの友達や近所の友 達との気持ちの行き違いから喧華も増えた.

ある日，本児はクラスメイトに勉強道具を片付ける よういわれたが応じなかったためその友達に頭を吒か れた。怒った本児は相手を引つ搔き, 取っ組み合いの 喧嘩になった。母親が先生から事情を聞いて「友達は こうへいができてなかったから教えてくれたんで」と いうと, 本児は「(友達の気持ちは) わかっとった」と 答え母親のことばを素直に聞いた。
このように喧嘩をしたり一緒に遊んだりを繰り返す 中で次第に友達の気持ちがわかり，ことばが通じる場 面が増えていった，ある日家族でみていたテレビにハ ワイの海が映り，母親が「あれはハワイの海で．綺麗 やなあ.」といった。すると本児は「由美子ちゃん=ク ラスメイトはお家でハワイにいったんだって。これが ハワイや!」といって喜んだ。自分の体験の中にない ことでも友達のことばがわかり，内容を理解しようと するようになった．また遊びの中でよく使う簡単なこ とばなら，一対一の場面で相手の顔をみないでもわか る時が出てきた。

重度難聴児の場合, 母親とのことばのやりとりが育 つには, 母子の情動的関係を基盤にし, まず体験を豊 かにしてそれを共有し，その意味（や概念）を表す記 号（身振りや表情など）を用いてやりとりし意味を共 有する.やがてこれがことばによるやりとりに移行し ていくということが知られている(大森 1995) ${ }^{5}$.

しかし身近な大人とのことばによるやりとりが成立 しても，それが友達とのことばのやりとりに移行する ことは難しい. 情動や体験の共有の乏しさ, 聞き取り の悪さやことばによる表現の未発達, 社会性の未成熟, 構音の不明瞭などが，ことばによるイメージの共有や ことばの意味概念について共通の理解を持つことを困 難にするからである (大森 1997 $)^{4)}$.

術前から友達と遊びたいという気持ちが育っていた 本児は, 人工内耳を通して友達の声が聞こえるように なると情動と行動, 体験を共有しようとするようにな り，やがて友達のことばを理解するようになった。そ の後喧嘩や遊びを繰り返す中で, さらに友達とのやり とりを深めた。この過程は大人とのことばのやりとり が育つ過程と共通であり，大人との間で成し遂げてき たことを再び友達との間で繰り返し，ことばによるや りとりを成立させることがわかった。

\section{ま と め}

(1)幼児期後半に人工内耳を装用した 1 症例の心身の 発達と音声言語の獲得過程を観察し, 人工内耳幼児症 例への援助を考えた。

(2)術前に，早期から母親との遊びを通して体験に基 づいた動作的理解一将来概念として整理されるもの一 やことばのやりとりを豊かに育てておくことが重要で あった。

(3)それら指導により育ったものをもとに, 装用後は 人工内耳からの聴覚情報を能動的に取り込み, 話しこ とばを獲得し, 友達とのことばのやりとりとりを成立 させていった。 


\section{文献}

1）野中信之，川野通夫，森 望，他：人工内耳幼 児症例の聴覚による言語獲得. Audiology Japan, $43 ： 44-53,2000$.

2）中村公枝：難聴乳幼児の治療教育. 平成 $2 \sim 4$ 年 度厚生省心身障害研究「治療教育の開発と統合化 に関する研究 (主任研究者：高橋彰彦)」難聴幼児 指導の手引き，93-148 頁，1993.

3）大森千代美, 傍士和香, 野中信之, 他: 人工内耳 を装用した先天性重度難聴幼児の構音獲得. 音声
言語医学, $42 ： 17-23,2001$.

4）大森千代美：第 8 章 2 万う・聴覚障害児 の生涯. 障害児心理 (中島 誠 編著) 仏教大学通信教育部, 京都, 288-302 頁, 1997.

5）大森千代美, 野中信之, 中川 弘, 他：一重度難 聴児の言語発達。音声言語医学 $36: 256-264$, 1995.

別刷請求先： ₹ 760-0080 高松市木太町 1997-3

香川こだま学園

大森千代美 